\title{
28 Research Square \\ Health Expenditure, Institutions, and Economic Growth: Insights From Selected MENA Countries
}

\section{Bashir Umar Faruk}

Federal University Gusau

Mohammad Imdadul Haque ( $\nabla$ dr.imdad.amu@gmail.com )

Aligarh Muslim University

Mohammad Rumzi Tausif

Prince Sattam bin Abdulaziz University

Md Riyazuddin Khan

University of Delhi

Research

Keywords: Health, Per capita income, Governance, Granger causality, Panel regression

Posted Date: August 5th, 2021

DOl: https://doi.org/10.21203/rs.3.rs-757523/v1

License: (c) (1) This work is licensed under a Creative Commons Attribution 4.0 International License. Read Full License 


\section{Abstract}

Health expenditure plays an important role in nation-building. Moreover, the current wave of the COVID-19 pandemic highlights the importance of health investments in maintaining a healthier economy across the world. Quite a significant number of empirical research undertaken on the relationship between health expenditure and economic growth produce mixed results. The study plans to study the relationship between health expenditure and economic growth and the role of institutions in causing health expenditure to promote growth. The study analyses this relationship using the case of seven selected MENA countries between 2000 and 2017. The Pedroni cointegration test reports a long-run cointegrating relationship between the variables. However, the Granger Causality test finds no casual relationships between health expenditure and economic growth. The study further applies panel OLS, FMOLS, and DOLS, and the result from all three models shows that health expenditure does not directly contribute to higher economic growth in the MENA countries. The study argues that this is possibly due to inadequate institutional quality. However, it is understandable that there must be indirect effects of health expenditure on economic growth through better human capital. Finally, the study discusses policy options to improve institutional quality indicators to tap the benefits and contribute positively to economic growth in the region.

\section{Introduction}

Investments in health increases workforce productivity which in turn reduces the loss in human capital owing to illness. Investments in health induce a decrease in mortality and morbidity, resulting in a rise in the ratio of the working-age population to the total population, rising per capita incomes (Bloom \& Canning, 2000). Health contributes to the nation, as people who are healthy are more active, more enthusiastic, and more productive (Loeppke et al., 2007). Health affects labour productivity, allowing for intellectual and physical growth (Jack \& Lewis, 2009). Therefore, health expenditure is instrumental in enhancing the 'human factor,' which impacts economic growth through either technical progress or labour productivity (Beraldo et al., 2009). In fact, investments in health contribute to the promotion of sustainable economic development (Chakrabarti, 2019; Nazar et al., 2020). Also, economic development strongly influences per capita health expenditure (Albulescu et al., 2017).

The healthcare system of the MENA region is engulfed in many systemic problems. The region has high rates of non-communicable diseases due to lifestyle changes and eating habits. Despite economic growth, governmental health expenditure has not grown at the rate of economic growth. This has led to a situation where the population has to spend more on getting health services. All these factors affect both the quality and quantity of healthcare services (Gottret \& Schieber, 2006; Asbu et al., 2017). Healthcare expenditure has risen due to increased health awareness, increases in technology related to health, and issues related to lifestyle. This poses further challenges to MENA because of a rise in the elderly population, an overall increase in population, and a surge in non-communicable and chronic diseases (Balkhi et al., 2020). This motivates the study role of health expenditure in the economic growth of the 
MENA region. Moreover, in light of the ongoing COVID-19 pandemic, a study of the health systems assumes further importance.

According to the WHO (2001), health status accounts for the difference in growth rates between countries. It states an estimate that there is a 0.3 to 0.4 percent increase in economic growth with a ten percent increase in life expectancy at birth. In fact, the report argues that many great take-offs were catalyzed by important developments in health systems in the history of the world economy.

Nevertheless, there are instances when the relationship between economic growth and health expenditure is unclear. As per Lewis (2006), this is due to destabilized health investments, which result from weak institutions, government failure, and lack of transparency. Low institutional quality leads to severe constraints on health, which hinders economic growth. Although the importance of healthcare investments in economic development is widely accepted, it depends on the country-specific quality of institutions as to whether further health investments will have a larger or smaller impact on the economic growth of the country (Sethi et al. 2020).

Institutions/governance has evolved as an important element to be considered together with health expenditure is governance. Governance is believed to be a primary determining factor of economic growth, social and development, and overall economic development. Governance ensures that investments in the health sector lead to economic growth (Piabuo \& Tieguhong, 2017). Unfortunately, governance in the field of health care is still not adequately understood (Siddiqi et al., 2009). Particularly in developing countries, rising health spending is determined not only by its demand and supply but also by institutional factors (Sahnoun, 2018). And when institutions are better, health investments result in higher economic growth (Rizvi, 2019). When the quality of institutions interacts positively with health capital, it leads to effective allocation of resources and furthers economic growth (Sarpong et al. 2020).

Though the healthcare system is one of the chief indicators of a country's development (Radojicic et al. 2020), the importance of health capital has only just caught the interest of researchers (Akingba et al. 2018; Silva et al. 2018). Despite its importance, the role of institutional quality in the relationship between economic growth and health expenditure is understudied (Sethi et al., 2020). Towards this, the study proceeds to study the role of health expenditure on the economic growth of the selected MENA countries. The innovation in this study is the incorporation of institutions/governance while controlling for factors like life expectancy, household consumption, labour force, and trade. Moreover, sparse studies in this respect on the MENA region add further importance to this study.

Also, two views related to health expenditure and growth reflect upon the bilateral relationship between the two (Bedir, 2016). The health view proposes that income is a function of health. Because of improvements in health or an increase in health expenditure, there is an increase in income. In contrast, the other income view proposes that health is a function of income. Income was identified as the most important factor explaining the variances between countries regarding the share and level of healthcare expenditure (Newhouse, 1977). This mechanism of reverse causality claims that as income increases, people demand more and better health services. These two views have been empirically tested by many 
studies like Piabuo and Tieguhong (2017) for African countries, Sarpong (et al. 2020) for sub-Saharan African, and Sethi (et al. 2020) for South Asian countries. This study plans to study this direction of causality for the countries in the MENA region. The remainder of this study is arranged as follows: literature review, data and methods, results and discussion, and finally, conclusion and recommendations.

\section{Literature review}

Previous empirical studies have reported a long-run cointegrating relationship between health expenditure and economic growth. Examples of these are Mehrara et al. (2012) for 13 countries in the MENA region and Piabuo and Tieguhong (2017) for 12 African countries. In a study on 53 countries, Jamison et al. (2005) found improvements in health attributed to $0.23 \%$ growth per year. In a study on twenty Pacific and southeast Asian developing countries, Rizvi (2019) reported that increasing health expenditures by $100 \%$ leads to a $5 \%$ increase in economic growth when adjusted for the quality of government expenditures. In another study on 35 sub-Saharan African (SSA), Sarpong et al. (2020) found that a $1 \%$ increase in health expenditure leads to a $0.20 \%$ increase in economic growth. For Algeria, Boussalem et al. (2014) found a cointegrating relationship between healthcare spending and economic growth. Sahnoun (2018), in his study on Tunisia, found that a $1 \%$ increase in health expenditure increased economic growth by $0.43 \%$.

Moreover, studies have studied the causal relationships between healthcare expenditure and economic growth. Piabuo and Tieguhong (2017) report a bi-directional causality between growth and health expenditure for countries with lower health expenditure, while there was only unilateral causality running from growth to health expenditure in countries with relatively higher health expenditure. Sarpong et al. (2020) found bidirectional causality between economic growth and health expenditure. Sethi et al. (2020) found bidirectional causality between economic growth and health expenditure. The study also established a unidirectional causality running from institutional quality to health expenditure. For Algeria, Boussalem et al. (2014) reported long-run causality running from public health spending to economic growth. For Nigeria, Alhassan et al. (2020) reported an insignificant negative impact of health expenditure on economic growth and reported unidirectional causality from health expenditure to economic growth.

For MENA countries, Lacheheb et al. (2014) found that health expenditure and education significantly impact economic growth positively, implying that investments in health and education will increase the economic growth of these countries. In another study on 19 OECD countries from 1971 to 1998, Beraldo et al. (2009) found that health and education expenditures contribute and compensate more than the distortions in the tax system caused by increased welfare expenditures. In another study on 92 countries, Silva and Andrade (2018) found that improved health is positively related to economic growth for the entire sample of countries and that countries facing economic slowdowns or comparatively poor growth rates benefit more from investments in health. For African countries, Piabuo and Tieguhong (2017) found a significantly positive effect of health expenditure on economic growth, which was higher for the group of countries that had allotted higher health expenditure. 
Contrarily, Churchill et al. (2015) is his study based on a meta-analysis of 306 estimates from 31 primary studies that reported a negative effect of government health expenditure on economic growth. The study explains the result with the argument that health expenditure leads to inefficient allocation of public resources and the crowding out of factors contributing to economic growth. This, along with distortionary taxation, tends to alter saving decisions and negatively impact growth as taxes are unnecessarily high. Because of this crowding out of both productive private and public resources and tax distortions, public health expenditure increases negatively impacts economic growth. This phenomenon is more probable in developed OECD and EU countries. Furthermore, these developed countries have an aging population with chronic illnesses and multi-morbidities. These elderly people need a lot of costly health care, but these healthcare investments do not directly promote productivity as they are not contributing to the workforce. Also, there are other factors like efficiency and quality of public health expenditure and poor mobility, resulting in an inefficient impact of an increase in health expenditure and improvements in human capital.

Also, in their study on Tunisia, Ghorbel and Kalai (2016) reported an inverse relationship between healthcare expenditure and economic growth, and causality tests also indicate an absence of a causal relationship between the two variables. And Mehrara and Musai (2011) found only a unidirectional effect from GDP to health expenditure and no causality running from health expenditure to economic growth. Alhowaish (2014), in his study on Saudi Arabia, found no cointegrating relationship between the variables but reported a unidirectional causality from economic growth to health spending. The study, however, reported no causality running from health spending to economic growth. Similarly, in their research on Nigeria, Nathaniel and Khan (2020) reported that public health expenditure did not implicitly contribute to the quality of life. This indicates mixed results on the relationship between health expenditure and economic growth, calling for further inspection.

\section{Data And Methods}

The study considers seven countries in the MENA region: Saudi Arabia, Iran, Oman, Qatar, Tunisia, Cyprus, and Israel. The study could not include all the remaining countries owing to the unavailability of data. The study covers the period from 2000 to 2017. The study considers GDP per capita as a proxy for economic growth, health expenditure as a percentage of GDP, life expectancy (proxy of health outcome), household consumption, labour force, trade as a percentage of GDP, and governance/institution. GDP per capita has been used as a proxy for economic growth in empirical studies like Mehrara et al. (2012), Alhassan et al. (2020), Sarpong et al. (2020), and Sethi et al. (2020). Governance represents a simple average of the World Bank governance indicators: "control of corruption, government effectiveness, political stability and absence of violence/terrorism, regulatory quality, the rule of law, voice and accountability." All variables except institutions are taken in natural log form. All the data is sourced from World Development Indicators and analyzed using E-views version 9.0.

This research adopted the theoretical model employed in the study by Piabuo and Tieguhong (2017), emphasizing the importance of human capital on economic growth. Specifically, the model has 
expressed a functional relationship between the main component of human capital (health expenditure) on one hand and economic growth on the other hand, as re-echoed in the endogenous growth model. The Functional relationship is, however, modified to include governance as follows:

$$
G D P_{i t}=\alpha_{i}+\beta_{i} H E_{i t}+\gamma_{i} H C_{i t}+\delta_{i} L E_{i t}+\omega_{i} L F_{i t}+\varphi_{i} T R_{i t}+\psi_{i} I N S_{i t}+\partial_{i} L H E * I N S_{i t}+\varepsilon_{i t}
$$

Where $\mathrm{i}$ is the individual country component, $\mathrm{t}$ stands for time component from 2000 to 2017 , $\mathrm{a}$ is an intercept and $\beta, \gamma, \delta, \omega, \varphi, \psi$ and $\partial$ are the coefficients and $\varepsilon$ is the error term.

GDP per capita represents economic growth, HE denotes health expenditure per capita, $\mathrm{HC}$ stands as Household Consumption expenditure, LE is an individual life expectancy at birth, the proportion of the population that makes up of the labour force is symbolized as LF, while TR represents trade as a percentage to GDP, which is the sum of exports and imports of goods and services. LHE* INS denotes the interaction terms between health expenditure and institution. The idea of incorporating trade is the postulation that a healthier society tends to have higher labour productivity, which would translate to an increase in the production of goods and services. Finally, INS signifies institutional quality or governance.

The first step is to test for the existence or otherwise of a unit root in our series, using panel unit root test, if results of the test using either ADF or PP fisher-type turned out to be I(1), that is integrated of order one, then Panel Co-integration test will be conducted using Panel cointegration technique developed by Pedroni $(1995,1999)$. This investigates the long-run relationship between the variables of interest under the null hypothesis of no cointegration against the alternative hypothesis. The Co-integration relationship is specified as follows:

$$
L G D P_{i t}=\alpha_{i}+\lambda_{t}+\beta_{i} L H E_{i t}+\gamma_{i} L H C_{i t}+\delta_{i} L L E_{i t}+\omega_{i} L L F_{i t}+\varphi_{i} L T R_{i t}+\psi_{i} I N S_{i t}+\partial L H E * I N S_{i t}+\varepsilon_{i t}
$$

Where $a_{i}$ implies country effects $\lambda_{t}$ and refers to trend effects. $\varepsilon_{i t}$ is the estimated residual showing the deviations from the long-run relationship.

This study employs the Granger Causality test to determine the direction of causality between health expenditure, economic growth and governance/institution, and other control variables. Moreover, Panel OLS, Fully Modified OLS, and Dynamic OLS estimation methods are also used to understand further the relationship between the cointegrating variables in the specified model.

\section{Results And Discussion}

From Fig. 1 below, the highest health expenditure per capita is observed in Israel, followed by Iran, Cyprus, Tunisia, Saudi Arabia, Oman, and Qatar over the years under study (2000-2017). In terms of health expenditure per capita, countries have different experiences. For Saudi Arabia, it decreased from 4.21$5.23 \%$ over the years, with fluctuations. For Iran, it increased from $4.73-8.65 \%$. For Oman, it was $3.06 \%$ in 2000, but it was less than 3\% for the period 2004 to 2013 and was 3.89\% in 2017. For Qatar, it increased 
from $2.00-2.60 \%$ over the years, with fluctuations. For Tunisia, it increased continuously from 5.04$7.23 \%$. For Cyprus, it shows a sharp increase from 5.30-6.68\%. For Israel, it indicates an upward trend from $6.80-7.40 \%$ over the sample periods.

Per capita GDP over the years under study (2000-2017) has shown a steady increase in all the selected MENA countries. The average GDP per capita is highest in Qatar, followed by Israel, Cyprus, Oman, Iran, Tunisia, and Saudi Arabia. A graphic description of GDP per capita and health expenditure as a percentage of GDP is provided in Fig. 1. Oman had the highest score in terms of institutional quality, followed by Qatar, Cyprus, and Tunisia. The remaining three countries had a negative score. The negative score in increasing order is Israel, followed by Saudi Arabia and Iran. Average life expectancy varies between 73 and 80 for the sample of countries. Further details on the control variables of Household consumption, labor force, trade are provided in the table on descriptive statistics (Appendix 1).

The study undertakes a unit roots test to ascertain whether there is any series of interest that contains a unit root. The Panel Unit roots test employed Im, Pesaran ND shin, ADF and PP Fisher-type tests, Levin, Lin \& Chu t ${ }^{*}$, and Breitung t-stat under the null hypothesis that individually the series is non-stationary against the alternative hypothesis. 
Table 1

Panel Unit root test Results

\begin{tabular}{|c|c|c|c|}
\hline Test method & Level & First difference & decision \\
\hline 1. Im, Pesaran and Shin W-Stat & Intercept \& Trend & Intercept \& Trend & \\
\hline 2. ADF-Fisher Chi-Square & Test stat. (p-value) & Test stat. (p-value) & \\
\hline \multicolumn{4}{|l|}{ 3. PP-Fisher Chi-Square } \\
\hline \multicolumn{4}{|l|}{ 4. Levin, Lin \& Chu $t^{\star}$} \\
\hline \multicolumn{4}{|l|}{ 5. Breitung t-stat } \\
\hline \multicolumn{4}{|l|}{ LGDP } \\
\hline 1 & $2.611(0.996)$ & $-4.425(0.000)$ & $\mathrm{I}(1)$ \\
\hline 2 & $5.190(0.983)$ & $43.561(0.000)$ & $\mathrm{I}(1)$ \\
\hline 3 & $3.860(0.996)$ & $67.181(0.000)$ & $\mathrm{I}(1)$ \\
\hline 4 & $0.329(0.629)$ & $-6.739(0.000)$ & $\mathrm{I}(1)$ \\
\hline 5 & $1.907(0.972)$ & $-2.488(0.006)$ & $\mathrm{I}(1)$ \\
\hline \multicolumn{4}{|l|}{ LHE } \\
\hline 1 & $1.056(0.855)$ & $-1.928(0.027)$ & $\mathrm{I}(1)$ \\
\hline 2 & $7.376(0.919)$ & $24.645(0.038)$ & $\mathrm{I}(1)$ \\
\hline 3 & $8.371(0.869)$ & $62.698(0.000)$ & $\mathrm{I}(1)$ \\
\hline 4 & $0.614(0.731)$ & $-0.528(0.299)$ & $\mathrm{I}(2)$ \\
\hline 5 & $-0.884(0.188)$ & $-1.759(0.039)$ & $\mathrm{I}(1)$ \\
\hline \multicolumn{4}{|l|}{ LLE } \\
\hline 1 & $-22.133(0.000)$ & $-11.134(0.000)$ & $\mathrm{I}(0)$ \\
\hline 2 & $101.961(0.000)$ & $94.967(0.000)$ & $\mathrm{I}(0)$ \\
\hline 3 & $18.311(0.193)$ & $35.781(0.001)$ & $\mathrm{I}(1)$ \\
\hline 4 & $-16.262(0.000)$ & $-12.653(0.000)$ & $\mathrm{I}(0)$ \\
\hline 5 & $-2.337(0.010)$ & $-0.868(0.193)$ & $\mathrm{I}(0)$ \\
\hline LHC & & & \\
\hline
\end{tabular}

Source: researchers' computation using Eviews 9.0 


\begin{tabular}{|c|c|c|c|}
\hline $\begin{array}{l}\text { Test method } \\
\text { 1. Im, Pesaran and Shin W-Stat } \\
\text { 2. ADF-Fisher Chi-Square } \\
\text { 3. PP-Fisher Chi-Square } \\
\text { 4. Levin, Lin \& Chu t* } \\
\text { 5. Breitung t-stat }\end{array}$ & $\begin{array}{l}\text { Level } \\
\text { Intercept \& Trend } \\
\text { Test stat. (p-value) }\end{array}$ & $\begin{array}{l}\text { First difference } \\
\text { Intercept \& Trend } \\
\text { Test stat. (p-value) }\end{array}$ & decision \\
\hline 1 & $2.538(0.994)$ & $-3.374(0.000)$ & $\mathrm{I}(1)$ \\
\hline 2 & $3.854(0.996)$ & $37.398(0.000)$ & $\mathrm{I}(1)$ \\
\hline 3 & $3.830(0.996)$ & $48.507(0.000)$ & $\mathrm{I}(1)$ \\
\hline 4 & $1.037(0.850)$ & $-4.371(0.000)$ & $\mathrm{I}(1)$ \\
\hline 5 & $1.853(0.968)$ & $-1.162(0.123)$ & $\mathrm{I}(2)$ \\
\hline \multicolumn{4}{|l|}{ LLF } \\
\hline 1 & $0.293(0.615)$ & $-0.415(0.339)$ & $\mathrm{I}(2)$ \\
\hline 2 & $14.715(0.398)$ & $20.430(0.117)$ & $\mathrm{I}(2)$ \\
\hline 3 & $6.592(0.949)$ & $33.565(0.002)$ & $\mathrm{I}(1)$ \\
\hline 4 & $-1.789(0.037)$ & $-1.947(0.026)$ & $\mathrm{I}(0)$ \\
\hline 5 & $2.386(0.992)$ & $0.599(0.725)$ & $\mathrm{I}(2)$ \\
\hline \multicolumn{4}{|l|}{ LTR } \\
\hline 1 & $-0.571(0.284)$ & $-2.768(0.003)$ & $\mathrm{I}(1)$ \\
\hline 2 & $17.063(0.253)$ & $29.673(0.009)$ & $\mathrm{I}(1)$ \\
\hline 3 & $10.049(0.759)$ & $60.385(0.000)$ & $\mathrm{I}(1)$ \\
\hline 4 & $-1.823(0.034)$ & $-2.945(0.002)$ & $\mathrm{I}(0)$ \\
\hline 5 & $1.272(0.898)$ & $-2.840(0.002)$ & $\mathrm{I}(1)$ \\
\hline
\end{tabular}

Source: researchers' computation using Eviews 9.0 


\begin{tabular}{|llll|}
\hline Test method & Level & First difference & decision \\
1. Im, Pesaran and Shin W-Stat & $\begin{array}{l}\text { Intercept \& Trend } \\
\text { Intercept \& Trend }\end{array}$ & \\
2. ADF-Fisher Chi-Square & Test stat. (p-value) & Test stat. (p-value) & \\
3. PP-Fisher Chi-Square & & & \\
4. Levin, Lin \& Chu t* & & & \\
5. Breitung t-stat & & & \\
\hline 1 & & $-5.594(0.000)$ & $\mathrm{I}(1)$ \\
2 & $0.778(0.782)$ & $51.721(0.000)$ & $\mathrm{I}(1)$ \\
3 & $9.193(0.819)$ & $89.801(0.000)$ & $\mathrm{I}(1)$ \\
4 & $18.083(0.203)$ & $-5.982(0.000)$ & $\mathrm{I}(1)$ \\
\hline 5 & $0.259(0.602)$ & $-3.160(0.000)$ & $\mathrm{I}(1)$ \\
\hline Source: researchers' computation using Eviews 9.0 & & \\
\hline
\end{tabular}

Table 1 above presents the panel unit root test results from well-known testing methods. However, the stationarity results based on PP-Fisher Chi-Square have shown that all the series of interests are not stationary. In other words, they are integrated of order one, i.e., I(1). Based on this result, the study went further to investigate whether the variables have a co-integration relation or not, using Pedroni cointegration test, under the null hypothesis of no-cointegration. 
Table 2

Panel cointegration test results

\begin{tabular}{|c|c|c|c|}
\hline $\begin{array}{l}\text { Pedroni residual Co-integration } \\
\text { test }\end{array}$ & & Statistic (P-value) & $\begin{array}{l}\text { Weighted statistic (P- } \\
\text { value) }\end{array}$ \\
\hline \multirow[t]{4}{*}{ Within-Dimension (Panel) } & Panel v-statistic & $1.3759(0.0844)$ & $-2.5771(0.9950)$ \\
\hline & $\begin{array}{l}\text { Panel rho- } \\
\text { statistic }\end{array}$ & $3.1560(0.9992)$ & $3.3774(0.9996)$ \\
\hline & $\begin{array}{l}\text { Panel PP- } \\
\text { statistic }\end{array}$ & $\begin{array}{l}-16.0120 \\
(0.0000)^{\star \star}\end{array}$ & \multirow[t]{2}{*}{$-2.1375(0.0163)^{\star}$} \\
\hline & $\begin{array}{l}\text { Panel ADF- } \\
\text { statistic }\end{array}$ & $\begin{array}{l}-4.0178 \\
(0.0000) * *\end{array}$ & \\
\hline \multirow{4}{*}{ Between-Dimension (Group) } & & \multicolumn{2}{|l|}{$4.4269(1.0000)$} \\
\hline & $\begin{array}{l}\text { Group rho- } \\
\text { statistic }\end{array}$ & \multicolumn{2}{|l|}{$\begin{array}{l}-10.6880 \\
(0.0000)^{\star \star}\end{array}$} \\
\hline & $\begin{array}{l}\text { Group PP- } \\
\text { statistic }\end{array}$ & \multirow{2}{*}{$\begin{array}{l}-5.0259 \\
(0.0000) \star \star\end{array}$} & \\
\hline & $\begin{array}{l}\text { Group ADF- } \\
\text { statistic }\end{array}$ & & \\
\hline
\end{tabular}

Based on the co-integration result displayed in Table 2 above, out of seven within-dimension and between-dimension tests, four are significant at a $1 \%$ significance level under normal statistics. However, the four within-dimension tests under the weighted statistics two are statistically significant, one at $1 \%$ and the other at a $5 \%$ significance level. Thus, we reject the null hypothesis and conclude that cointegration exists between the variables.

In other words, there is a long-run co-integrating relationship between economic growth (GDP per capita), health expenditure, health outcome (life expectancy), household consumption expenditure, labour force, trade, and institutional quality or governance. This supports the earlier finding for the MENA region by Lacheb et al. (2014) and Mehrara et al. (2014), who have equally found a long-run cointegrating relationship between economic growth and health expenditure. A similar cointegrating relationship has been reported by Boussalem et al. (2014), Piabuo and Tieguhong (2017), Sahnoun (2018), Rizvi (2019), Sarpong et al. (2020), and Sethi et al. (2020)

However, to identify the direction of causality between these variables, the study employs a pair-wise Granger causality test. The null hypothesis states that there is no Granger causality between the 
variables. The test further indicates whether the direction of the causality (if any) is unidirectional, bidirectional, or no-directional. 
Table 3

Granger causality test result

\begin{tabular}{|c|c|c|c|}
\hline Null Hypothesis (Does not Granger cause. The sign indicates it $\nRightarrow$ ) & Obs & F-statistics & Prob. \\
\hline $\mathrm{LHE} \nRightarrow \mathrm{LGDP}$ & 112 & 0.59706 & 0.5523 \\
\hline LGDP $\nRightarrow$ LHE & & 0.43767 & 0.6467 \\
\hline LLE $\nRightarrow$ LGDP & 112 & 0.35749 & 0.7003 \\
\hline LGDP $\nRightarrow$ LLE & & 0.65820 & 0.5199 \\
\hline $\mathrm{LHC} \nRightarrow \mathrm{LGDP}$ & 112 & 1.34349 & 0.2953 \\
\hline $\mathrm{LGDP} \nRightarrow \mathrm{LHC}$ & & 1.20999 & 0.3022 \\
\hline $\mathrm{LLF} \nRightarrow \mathrm{LGDP}$ & 112 & 1.74357 & 0.1798 \\
\hline$L G D P \nRightarrow L L F$ & & 1.92686 & 0.1505 \\
\hline $\mathrm{LTR} \nRightarrow \mathrm{LGDP}$ & 112 & 0.36347 & 0.6961 \\
\hline LGDP $\nRightarrow \mathrm{LTR}$ & & 0.34461 & 0.7093 \\
\hline INS $\nRightarrow$ LGDP & 98 & 2.31004 & 0.1049 \\
\hline LGDP $\nRightarrow$ INS & & 2.13358 & 0.1242 \\
\hline $\mathrm{LLE} \nRightarrow \mathrm{LHE}$ & 112 & 0.00584 & 0.9942 \\
\hline $\mathrm{LHE} \nRightarrow \mathrm{LLE}$ & & 0.26777 & 0.7656 \\
\hline $\mathrm{LHC} \nRightarrow \mathrm{LHE}$ & 112 & 1.00208 & 0.3705 \\
\hline $\mathrm{LHE} \nRightarrow \mathrm{LHC}$ & & 2.20907 & 0.1148 \\
\hline $\mathrm{LLF} \nRightarrow \mathrm{LHE}$ & 112 & 4.14930 & $0.0184^{\star \star}$ \\
\hline $\mathrm{LHE} \nRightarrow \mathrm{LLF}$ & & 0.66214 & 0.5178 \\
\hline $\mathrm{LTR} \nRightarrow \mathrm{LHE}$ & 112 & 0.20146 & 0.8178 \\
\hline $\mathrm{LHE} \nRightarrow \mathrm{LTR}$ & & 0.23452 & 0.7914 \\
\hline INS $\nRightarrow \mathrm{LHE}$ & 98 & 0.94923 & 0.3908 \\
\hline $\mathrm{LHE} \nRightarrow \mathrm{INS}$ & & 2.33660 & 0.1023 \\
\hline $\mathrm{LHC} \nRightarrow \mathrm{LLE}$ & 112 & 0.01787 & 0.9823 \\
\hline $\mathrm{LLE} \nRightarrow \mathrm{LHC}$ & & 1.13490 & 0.3253 \\
\hline $\mathrm{LLF} \nRightarrow \mathrm{LLE}$ & 112 & 0.33984 & 0.7126 \\
\hline LLE $\nRightarrow$ LLF & & 2.03204 & 0.1361 \\
\hline $\mathrm{LTR} \nRightarrow \mathrm{LLE}$ & 112 & 2.66987 & $0.0739^{*}$ \\
\hline
\end{tabular}




\begin{tabular}{|c|c|c|c|}
\hline LLE $\nRightarrow \mathrm{LTR}$ & & 0.14512 & 0.8651 \\
\hline INS $\nRightarrow$ LLE & \multirow[t]{2}{*}{98} & 1.74545 & 0.1802 \\
\hline LLE $\nRightarrow I N S$ & & 0.37084 & 0.6912 \\
\hline $\mathrm{LLF} \nRightarrow \mathrm{LHC}$ & \multirow[t]{2}{*}{112} & 3.96216 & $0.0219^{\star *}$ \\
\hline $\mathrm{LHC} \nRightarrow \mathrm{LLF}$ & & 2.15085 & 0.1214 \\
\hline $\mathrm{LTR} \nRightarrow \mathrm{LHC}$ & \multirow[t]{2}{*}{112} & 1.54621 & 0.2178 \\
\hline $\mathrm{LHC} \nRightarrow \mathrm{LTR}$ & & 4.92108 & $0.0090^{\star \star \star}$ \\
\hline $\mathrm{INS} \nRightarrow \mathrm{LHC}$ & \multirow[t]{2}{*}{98} & 2.84191 & $00634^{*}$ \\
\hline $\mathrm{LHC} \nRightarrow \mathrm{INS}$ & & 0.09852 & 00052 \\
\hline $\mathrm{LTR} \nRightarrow \mathrm{LLF}$ & \multirow[t]{2}{*}{112} & 2.27720 & 01075 \\
\hline $\mathrm{LLF} \nRightarrow \mathrm{LTR}$ & & 2.19892 & 01150 \\
\hline INS $\nRightarrow$ LLF & \multirow[t]{2}{*}{98} & 0.84196 & 01341 \\
\hline $\mathrm{LLF} \nRightarrow \mathrm{INS}$ & & 1.13066 & 2. \\
\hline INS $\nRightarrow \mathrm{LTR}$ & \multirow[t]{3}{*}{98} & 2.93999 & \\
\hline $\mathrm{LTR} \nRightarrow \mathrm{INS}$ & & 0.41714 & $0.0578^{*}$ \\
\hline & & & 0.6602 \\
\hline
\end{tabular}

Results show no causal relationship of GDP per capita with any other variables (Table 3). Specifically, the study finds no causality between economic growth and health expenditure. This goes against Piabuo and Tieeeguhong's (2017) findings, which reports bidirectional causality between health expenditure and economic growth for countries with lower health expenditure and unidirectional causality running from health expenditure to economic growth for countries with higher health expenditure. The current study results also go against the findings of Sarpong et al. (2020) and Sethi et al. (2020), which report a bidirectional causality between economic growth and health expenditure. The result is in contrast to findings of unidirectional causality from health expenditure to economic growth of Boussalem et al. (2014) and Alhassan et al. (2020); and unidirectional causality from economic growth to health expenditure of Mehrara and Musai (2011) and Alhowaish (2014). The only previous study with a similar result of no causality between health expenditure and economic growth is Ghorbel and Kalai (2016).

However, labour force Granger causes health expenditure, but health expenditure does not Granger causes labour force. The Granger causality test result indicates that trade causes life expectancy, but life expectancy does not cause trade. Similarly, causality between labour force and household consumption expenditure runs from the labour force to household consumption and not the other way round. 
Furthermore, a unidirectional relationship is also found between household consumption expenditure and trade, household consumption and institutions with the causality running from household consumption expenditure to trade, also from institutions to household consumption and not the reverses. The result equally shows a unidirectional relationship running from institutions to trade. All other relations were found not to have a causal link in between. Particularly with reference to institutions, the results of this study contradict Sethi et al. (2020), which found unidirectional causality running from institutions to health expenditure.

Table 4

Panel Regression Results

\begin{tabular}{|c|c|c|c|}
\hline \multirow{2}{*}{$\begin{array}{l}\text { GDP per capita (Dependent } \\
\text { variable) }\end{array}$} & \multirow{2}{*}{$\begin{array}{l}\text { Panel OLS } \\
\text { Coefficient(P-value) }\end{array}$} & \multirow{2}{*}{$\begin{array}{l}\text { FMOLS } \\
\text { Coefficient(P- } \\
\text { value) }\end{array}$} & \multirow{2}{*}{$\begin{array}{l}\text { DOLS } \\
\text { Coefficient(P-value) }\end{array}$} \\
\hline & & & \\
\hline LHE & $-1.516(0.000)^{\star \star}$ & $-0.318(0.000)^{\star \star}$ & $-0.375(0.000) \star *$ \\
\hline LLE & 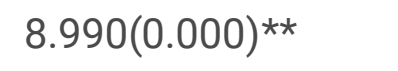 & $-3.486(0.580)$ & $-4.297(0.473)$ \\
\hline LHC & $0.921(0.000)^{\star \star}$ & $1.012(0.000)^{\star \star}$ & 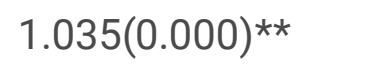 \\
\hline LLF & $-0.974(0.000)^{\star \star}$ & $-0.481(0.000)^{\star \star}$ & $-0.490(0.001)^{\star \star}$ \\
\hline LTR & $0.083(0.561)$ & $0.448(0.000)^{\star \star}$ & $0.429(0.000)^{\star \star}$ \\
\hline INS & $-0.099(0.002)^{\star \star}$ & $0.043(0.095)$ & $0.013(0.644)$ \\
\hline LHE*INS & $0.025(0.254)$ & $-0.029(0.064)$ & $-0.014(0.398)$ \\
\hline C & $-35.359(0.000) \star \star$ & - & - \\
\hline R-Square & 0.957 & 0.996 & 0.996 \\
\hline Adjusted R-Square & 0.954 & 0.995 & 0.995 \\
\hline Long -Run Variance & & 0.0038 & 0.0057 \\
\hline
\end{tabular}

From Table 4 above, a significant negative relationship is noticed between health expenditure (LHE) and GDP per capita on the one hand, and also between Labour Force (LLF) and GDP in another hand in all the three models, namely panel OLS, Fully Modified OLS (FMOLS) and Dynamic panel OLS (DOLS) that a unit change in health expenditure or labour force will lead to a declining level of GDP per capita. A similar finding of the negative impact of health expenditure on economic growth has been reported previously by Mehrara et al. (2014), Churchill et al. (2015), and Ghorbel and Kalai (2016). However, the finding contradicts studies like Lacheheb et al. (2014), Piabuo and Tieguhong (2017), Rizvi (2019), Sarpong et al. (2020), Sethi et al. (2020), Boussalem et al. (2014), and Sahnoun (2018). 
On the other hand, there is a positive and statistically significant relationship between household consumption expenditure (LHC) and GDP per capita in all three models. Similarly, trade (LTR) and GDP per capita bear positive and significant relationships in FMOLS and DOLS, although in Panel OLS, the association is positive; still, it is statistically insignificant. This implies that increased household consumption expenditure and trade levels will result in a corresponding increase in economic growth per capita in the selected MENA countries. Again, life expectancy (LLE) bears a positive and statistically significant relation to GDP per capita in the panel OLS model but a negative and insignificant relationship in FMOLS and DOLS models.

The results of Panel OLS show that intuitions have a negative contribution to growth, while the results of FMOLS and DOLS show an insignificant contribution of institutions to economic growth. More importantly, the interaction terms of institutions and health expenditure are not significant. This contradicts the findings of Sarpong et al. (2020) that interaction between health expenditure and institutional quality is significant. This implies that in the sample of countries studied here, institutions are not interacting in a positive way so that health expenditure increases economic growth.

A significant contribution of this study is the incorporation of institutions in the relationship between health expenditure and economic growth. This, according to Sethi et al. (2020), is still not extensively researched. Also, the authors find no such study, particularly with reference to the MENA region. An earlier study by Rizvi (2019) observed that health investments lead to higher economic growth when institutions are better. Also, Sarpong et al. (2020) observed that only when intuitions interact positively with health capital then it furthers economic growth. This study finds that institutional quality is not supportive to positively impact the relationship between health expenditure and per capita income in the selected countries under study.

\section{Conclusion And Recommendation}

The study finds a negative relationship between health expenditure and economic growth. This result questions the healthcare systems prevalent in the sample of countries. It implies that increased health care spending alone would not guarantee high economic growth; other factors (such as good governance, increased household consumption expenditure, trade, life expectancy) must be put in place to support and ensure a positive response of health expenditure on growth. This claim was further supported with the establishment of a long-run equilibrium relationship between the variables.

This negative relationship indicates that a significant portion of these health investments is unproductive. This may be because huge spending on health care is majorly on the elderly and under-age population segment, which is not a part of the workforce, thereby contributing little or nothing to economic growth. Supporting this, the study found no causality between health expenditure and economic growth. Towards this, the study identifies an in-depth accounting of health expenditure on the unproductive segment of the population as its scope for future research. Finally, this study recommends enhancing institutional quality indicators to aid health expenditure in stimulating economic growth. 


\section{Declarations}

Competing interests: The authors declare that they have no competing interests.

Ethics approval and consent to participate: Not applicable

Consent for publication: Not applicable

Availability of data and material: The datasets generated during and/or analysed during the current study are available in the World Bank Development Indicator repository using the weblink [https://datacatalog.worldbank.org/dataset/world-development-indicators]

Competing interests: The authors declare that they have no competing interests.

Funding: Not applicable

Acknowledgements: Not applicable

Authors' contributions: M.I.H and B.U.F conceived the idea for the research. M.I.H and B.U.F. contributed to all other aspects including data analysis, interpretation, and manuscript preparation and writing. M.R.T., and M.R.K. provided inputs to analysis and contributed to manuscript writing. All co-authors read and approved the final version of the manuscript.

\section{References}

1. Akingba, I. O. I., Kaliappan, S. R., \& Hamzah, H. Z. (2018). Impact of health capital on economic growth in Singapore: an ARDL approach to cointegration. International Journal of Social Economics, 45(2), 340-356.

2. Albulescu, C., Oros, C., \& Tiwari, A. K. (2017). Is there any convergence in health expenditures across EU countries?. Economics Bulletin, 37(3), 2095-2101.

3. Alhassan, G. N., Adedoyin, F. F., Bekun, F. V., \& Agabo, T. J. (2020). Does life expectancy, death rate and public health expenditure matter in sustaining economic growth under COVID-19: Empirical evidence from Nigeria?. Journal of Public Affairs, e2302.

4. Alhowaish, A. K. (2014). Healthcare spending and economic growth in Saudi Arabia: A Granger causality approach. International Journal of Scientific \& Engineering Research, 5(1), 1471-1476.

5. Asbu, E. Z., Masri, M. D., \& Kaissi, A. (2017). Health status and health systems financing in the MENA region: roadmap to universal health coverage. Global health research and policy, 2(1), 1-13.

6. Balkhi, B., Alshayban, D., \& Alotaibi, N. M. (2020). Impact of Healthcare Expenditures on Healthcare Outcomes in the Middle East and North Africa (MENA) Region: A Cross-Country Comparison, 19952015. Frontiers in public health, 8.

7. Bedir, S. (2016). Healthcare expenditure and economic growth in developing countries. Advances in Economics and Business, 4(2), 76-86. 
8. Beraldo, S., Montolio, D., \& Turati, G. (2009). Healthy, educated and wealthy: A primer on the impact of public and private welfare expenditures on economic growth. The Journal of Socio-Economics, 38(6), 946-956.

9. Bloom, D. E., \& Canning, D. (2000). The health and wealth of nations. Science, 287(5456), 1207-1209.

10. Boussalem, F., Boussalem, Z., \& Taiba, A. (2014). The relationship between public spending on health and economic growth in Algeria: Testing for co-integration and causality. International journal of business and management, 2(3), 25.

11. Chakrabarti, S., Khan, M. T., Kishore, A., Roy, D., \& Scott, S. P. (2019). Risk of acute respiratory infection from crop burning in India: estimating disease burden and economic welfare from satellite and national health survey data for 250000 persons. International journal of epidemiology, 48(4), 1113-1124.

12. Churchill, S. A., Yew, S. L., \& Ugur, M. (2015). Effects of Government Education and Health Expenditures on Economic Growth: A Meta- analysis. Greenwich Political Economic Research Centre. No: GPERC21.

13. Ghorbel, A., \& Kalai, M. (2016). Health expenditure, human capital and economic growth in Tunisia: An ARDL bounds testing approach. Journal of Business Management and Economics, 4(8), 36-45.

14. Gottret, P., \& Schieber, G. (2006). Health financing revisited: a practitioner's guide. The World Bank.

15. Jack, W. (1999). Principles of health economics for developing countries. World Bank Publications.

16. Jamison, D. T., Lau, L. J., \& Wang, J. (2005). Health's contribution to economic growth in an environment of partially endogenous technical progress. Health and economic growth: Findings and policy implications, 67-91.

17. Lacheheb, M., Med Nor, N., \& Baloch, I. (2014). Health expenditure, education and economic growth in MENA countries. MPRA Paper No. 60388.

18. Lewis, M. (2006). Governance and corruption in public health care systems. Center for Global Development working paper, (78).

19. Loeppke, R., Taitel, M., Richling, D., Parry, T., Kessler, R. C., Hymel, P., \& Konicki, D. (2007). Health and productivity as a business strategy. Journal of Occupational and Environmental Medicine, 49(7), 712-721.

20. Mehrara, M., \& Musai, M. (2011). The causality between health expenditure and economic growth in Iran. Int. J. Eco. Res, 2(4), 13-19.

21. Mehrara, M., Fazaeli, A. A., Fazaeli, A. A., \& Fazaeli, A. R. (2012). The relationship between health expenditures and economic growth in Middle East \& North Africa (MENA) countries. International Journal of Business Management and Economic Research, 3(1), 425-428.

22. Nazar, R., Meo, M. S., \& Ali, S. (2020) Role of public health and trade for achieving sustainable development goals. Journal of Public Affairs, e2585.

23. Nathaniel, S., \& Khan, S. (2020). Public health financing, environmental quality, and the quality of life in Nigeria. Journal of Public Affairs, 20(3), e2103. 
24. Newhouse, J. P. (1977). Medical-care expenditure: a cross-national survey. The Journal of human resources, 12(1), 115-125.

25. Piabuo, S. M., \& Tieguhong, J. C. (2017). Health expenditure and economic growth-a review of the literature and an analysis between the economic community for central African states (CEMAC) and selected African countries. Health economics review, 7(1), 1-13.

26. Radojicic, M., Jeremic, V., \& Savic, G. (2020). Going beyond health efficiency: What really matters?. The International journal of health planning and management, 35(1), 318-338.

27. Rizvi, S. A. F. (2019). Health Expenditures, Institutional Quality and Economic Growth. Empirical Economic Review, 2(1), 63-82.

28. Sahnoun, M. (2018). Does Health Expenditure Increase Economic Growth: Evidence from Tunisia. Romanian Economic Journal, 20(67), 126-144.

29. Sarpong, B., Nketiah-Amponsah, E., \& Owoo, N. S. (2020). Health and economic growth nexus: Evidence from selected sub-Saharan African (SSA) countries. Global Business Review, 21(2), 328347.

30. Sethi, N., Mohanty, S., Das, A., \& Sahoo, M. (2020). Health Expenditure and Economic Growth Nexus: Empirical Evidence from South Asian Countries. Global Business Review, 0972150920963069.

31. Siddiqi, S., Masud, T. I., Nishtar, S., Peters, D. H., Sabri, B., Bile, K. M., \& Jama, M. A. (2009). Framework for assessing governance of the health system in developing countries: gateway to good governance. Health policy, 90(1), 13-25.

32. Silva, F. R., Simões, M., \& Andrade, J. S. (2018). Health investments and economic growth: a quantile regression approach. International Journal of Development Issues, 17(2), 220-245.

33. World Health Organization. (2000). The world health report 2000: health systems: improving performance. World Health Organization.

34. World Health Organization. (2001). Macroeconomics and health: investing in health for economic development: report of the Commission on Macroeconomics and Health. In Macroeconomics and health: investing in health for economic development: report of the commission on macroeconomics and health (pp. 202-202).

35. Yang, X. (2019). Health expenditure, human capital, and economic growth: an empirical study of developing countries. International journal of health economics and management, 1-14.

\section{Appendix}




\begin{tabular}{|c|c|c|c|c|c|}
\hline Variable & Obs & Mean & Std. Dev. & Min & Max \\
\hline \multicolumn{6}{|c|}{ Saudi Arabia } \\
\hline GDP & 18 & 17116.78 & 5854.749 & 8684.647 & 25243.36 \\
\hline HE & 18 & 4.249141 & 0.840263 & 2.971004 & 5.998345 \\
\hline LE & 18 & 73.74206 & 0.725867 & 72.561 & 74.874 \\
\hline $\mathrm{HC}$ & 18 & $1.56 \mathrm{E}+11$ & $7.81 \mathrm{E}+10$ & $6.86 E+10$ & $2.84 \mathrm{E}+11$ \\
\hline LF & 18 & 9703658 & 2519585 & 6358134 & $1.38 \mathrm{E}+07$ \\
\hline TR & 18 & 77.89056 & 10.84701 & 61.86 & 96.1 \\
\hline INS & 17 & -2.05094 & 0.416286 & -2.90032 & -1.28494 \\
\hline \multicolumn{6}{|l|}{ Iran } \\
\hline GDP & 18 & 4635.8 & 1978.767 & 1670.009 & 7927.847 \\
\hline HE & 18 & 6.138222 & 1.292943 & 4.735038 & 8.859507 \\
\hline LE & 18 & 73.31122 & 2.002135 & 70.176 & 76.271 \\
\hline $\mathrm{HC}$ & 18 & $1.56 \mathrm{E}+11$ & $7.25 E+10$ & $5.45 E+10$ & $2.85 E+11$ \\
\hline LF & 18 & $2.37 E+07$ & 2035901 & $1.92 E+07$ & $2.74 \mathrm{E}+07$ \\
\hline TR & 18 & 46.20333 & 4.274876 & 39.02 & 54.44 \\
\hline INS & 17 & -5.81601 & 0.949159 & -7.39392 & -4.58884 \\
\hline \multicolumn{6}{|l|}{ Oman } \\
\hline GDP & 18 & 15272.99 & 4871.676 & 8475.964 & 22139.64 \\
\hline HE & 18 & 3.020174 & 0.641347 & 2.012227 & 4.328745 \\
\hline LE & 18 & 75.08533 & 1.603945 & 72.126 & 77.393 \\
\hline $\mathrm{HC}$ & 18 & $1.67 E+10$ & $7.79 E+09$ & $6.90 E+09$ & $2.94 \mathrm{E}+10$ \\
\hline LF & 18 & 1440293 & 625443.2 & 786494 & 2601786 \\
\hline TR & 18 & 97.55222 & 15.16263 & 77.02 & 128.47 \\
\hline INS & 17 & 6.085085 & 0.505079 & 5.210553 & 7.045288 \\
\hline \multicolumn{6}{|l|}{ Qatar } \\
\hline GDP & 18 & 59241.78 & 19782.07 & 28517.27 & 85076.15 \\
\hline $\mathrm{HE}$ & 18 & 2.349446 & 0.559585 & 1.599962 & 3.52964 \\
\hline LE & 18 & 78.79933 & 0.81964 & 77.467 & 79.981 \\
\hline
\end{tabular}




\begin{tabular}{|c|c|c|c|c|c|}
\hline Variable & Obs & Mean & Std. Dev. & Min & Max \\
\hline $\mathrm{HC}$ & 18 & $1.84 \mathrm{E}+10$ & $1.31 E+10$ & $2.70 \mathrm{E}+09$ & $4.11 E+10$ \\
\hline LF & 18 & 1138481 & 647402.2 & 339550 & 2046136 \\
\hline TR & 18 & 93.67167 & 7.752752 & 80.14 & 115.75 \\
\hline INS & 17 & 3.745505 & 0.513002 & 2.954333 & 4.90917 \\
\hline \multicolumn{6}{|l|}{ Tunisia } \\
\hline GDP & 18 & 3532.447 & 736.707 & 2211.827 & 4307.156 \\
\hline HE & 18 & 5.975273 & 0.754828 & 5.048344 & 7.232457 \\
\hline LE & 18 & 74.78461 & 0.947393 & 73.172 & 76.31 \\
\hline $\mathrm{HC}$ & 18 & $2.44 \mathrm{E}+10$ & $6.66 \mathrm{E}+09$ & $1.30 \mathrm{E}+10$ & $3.29 E+10$ \\
\hline LF & 18 & 3661197 & 298753.7 & 3221210 & 4036987 \\
\hline TR & 18 & 95.79889 & 9.069415 & 82.39 & 114.35 \\
\hline INS & 17 & 1.545363 & 0.675057 & 0.554355 & 2.794327 \\
\hline \multicolumn{6}{|l|}{ Cyprus } \\
\hline GDP & 18 & 25621.33 & 6117.937 & 14388.35 & 35397.36 \\
\hline HE & 18 & 6.086978 & 0.628592 & 5.308001 & 6.901281 \\
\hline LE & 18 & 79.24989 & 0.859273 & 78.009 & 80.672 \\
\hline $\mathrm{HC}$ & 18 & $1.33 E+10$ & $4.03 E+09$ & $6.18 \mathrm{E}+09$ & $1.86 \mathrm{E}+10$ \\
\hline LF & 18 & 549545.9 & 53553.54 & 445184 & 611083 \\
\hline TR & 18 & 121.0394 & 13.07488 & 102.79 & 146.4 \\
\hline INS & 17 & 2.902857 & 0.793854 & 1.964489 & 4.345609 \\
\hline \multicolumn{6}{|l|}{ Israel } \\
\hline GDP & 18 & 28209.84 & 7583.515 & 18435.89 & 40541.86 \\
\hline HE & 18 & 7.079995 & 0.147256 & 6.807063 & 7.407464 \\
\hline LE & 18 & 80.96423 & 1.143109 & 78.95366 & 82.55122 \\
\hline $\mathrm{HC}$ & 18 & $1.19 \mathrm{E}+11$ & $4.31 E+10$ & $6.70 E+10$ & $1.93 E+11$ \\
\hline LF & 18 & 3373460 & 407574.5 & 2768248 & 4024831 \\
\hline TR & 18 & 69.58722 & 8.046768 & 57.21 & 81.84 \\
\hline INS & 17 & -0.96816 & 0.533833 & -1.67494 & -0.04985 \\
\hline
\end{tabular}


Figures

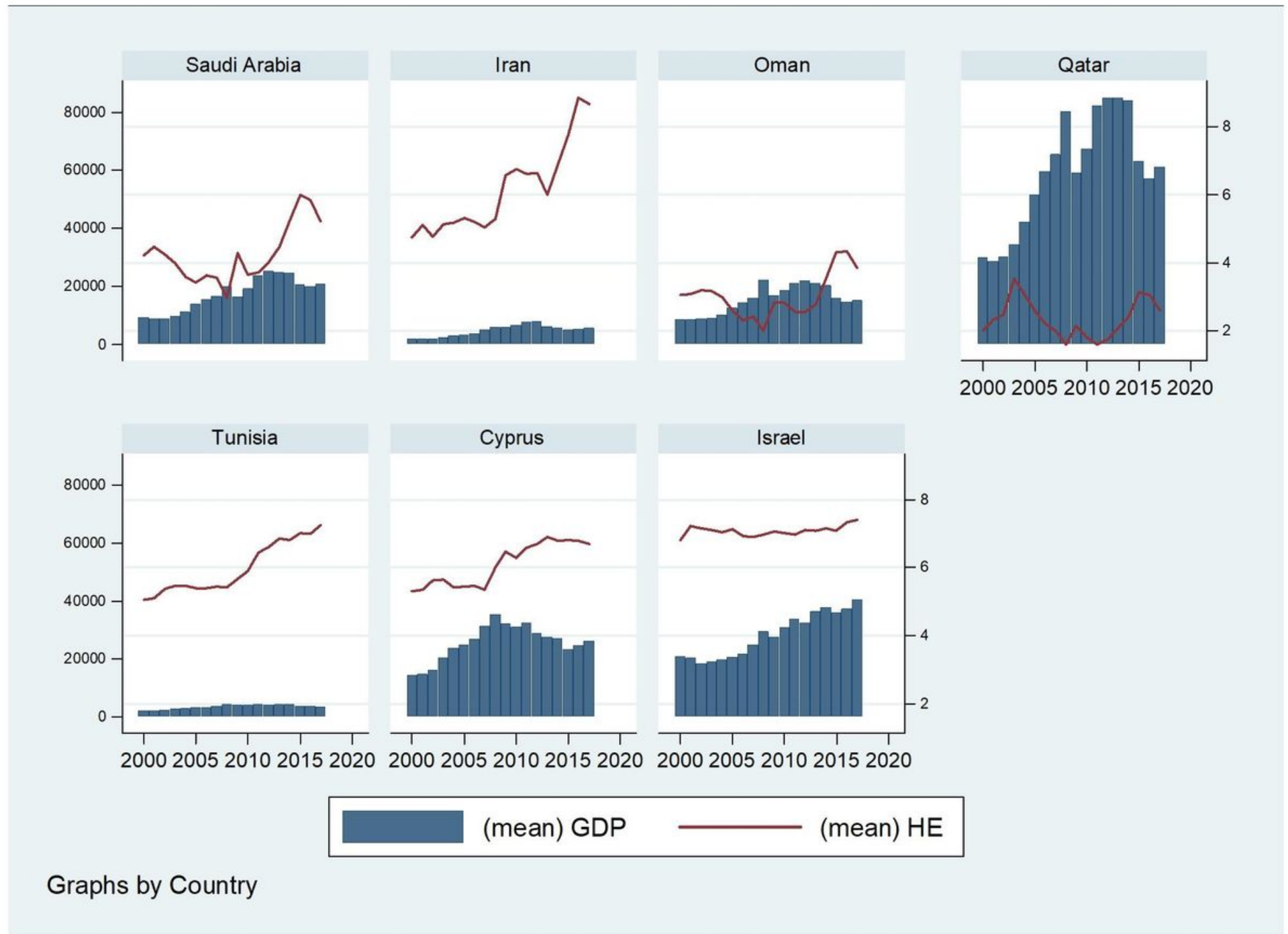

Figure 1

GDP per capita and Health expenditure as a percentage of GDP 